ADVANCES IN ANIMAL WELFARE SCIENCE 1984 


\title{
ADVANCES IN ANIMAL WELFARE SCIENCE 1984
}

\author{
edited by \\ Michael W. Fox, D.Sc., Ph.D., B.Vet.Med., MRCVS \\ Director, The Institute for the Study of Animal Problems \\ Washington, DC 20037, USA
}

and

Linda D. Mickley B.S.

Research Associate, The Institute for the Study of Animal Problems Washington DC 20037, USA 


\section{Distributors}

for the United States and Canada: Kluwer Academic Publishers, 190 Old Derby Street, Hingham, MA 02043, USA

for the UK and Ireland: Kluwer Academic Publishers, MTP Press Limited, Falcon House, Queen Square, Lancaster LA1 1RN, UK

for all other countries: Kluwer Academic Publishers Group, Distribution Center, P.O. Box 322, 3300 AH Dordrecht, The Netherlands

\section{Library of Congress Cataloging in Publication Data}

ISBN-13: 978-94-010-8713-1

e-ISBN-13: 978-94-009-4998-0

DOI: $10.1007 / 978-94-009-4998-0$

\section{Copyright}

(C) 1985 by Martinus Nijhoff Publishers, Dordrecht.

Softcover reprint of the hardcover 1st edition 1985

All rights reserved. No part of this publication may be reproduced, stored in a retrieval system, or transmitted in any form or by any means, mechanical, photocopying, recording, or otherwise, without the prior written permission of the publishers, Martinus Nijhoff Publishers, P.O. Box 163, 3300 AD Dordrecht, The Netherlands. 


\section{MANUSCRIPT REVIEW COMMITTEE ADVANCES IN ANIMAL WELFARE SCIENCE}

Judith K. Blackshaw Department of Animal Production, University of Queensland, St. Lucia, Brisbane, Australia

Gordon M. Burghardt Department of Psychology, University of Tennessee, Knoxville, Tennessee, USA

Ned Buyukmihci School of Veterinary Medicine, Department of Surgery, University of California, Davis, California, USA

Marian Dawkins Animal Behaviour Research Group, Dept. of Zoology, University of Oxford, United Kingdom

Detlef W. Fölsch Institut fur Tierproduktion, Zurich, Switzerland

Andrew F. Fraser Memorial University of Newfoundland, Faculty of Medicine, Health Science Center, St. John's, Newfoundland, Canada

Ted H. Friend, Jr. Department of Animal Science, Texas A\&M University, College Station, Texas, USA

John Grandy The Humane Society of the United States, Washington, D.C., USA

W. B. Gross Department of Veterinary Science, Virginia Polytechnic Institute, Blacksburg, Virginia, USA

Katherine Houpt Department of Physiology, New York State Veterinary College, Cornell University, Ithaca, New York, USA

John A. Hoyt The Humane Society of the United States, Washington, D.C., USA 
B. O. Hughes Agricultural Poultry Research Centre, Roslin, Midlothian, Scotland

Frank Hurnik Department of Animal Science, University of Guelph, Guelph, Canada

Ron Kilgour Ministry of Agriculture and Fisheries, Ruakura Animal Research Station, Hamilton, New Zealand

Devra Kleiman National Zoological Park, Smithsonian Institution, Washington, D.C., USA

Elizabeth A. Lawrence Tufts University, School of Veterinary Medicine, Boston, Massachusetts, USA

Michael J. McCulloch Northwest Resource Group of Mental Health, Portland, Oregon, USA

Jenny Remfry Universities Federation for Animal Welfare, Potters Bar, Herts, England

Bernard E. Rollin Department of Philosophy, Colorado State University, Fort Collins, Colorado, USA

Andrew N. Rowan Tufts University, School of Veterinary Medicine, Boston, Massachusetts, USA

Harry C. Rowsell Canadian Council on Animal Care, Ottawa, Ontario, Canada

Joyce S. A. Tischler Attorneys for Animal Rights, San Anselmo, California, USA

G. van Putten Research Institute for Animal Production, "Schoonoord", Zeist, Holland

D. B. Wilkins Royal Society for the Prevention of Cruelty to Animals, The Causeway, Horsham, Sussex, England

Thomas Wolfle National Institutes of Health, Department of Health and Human Services, Bethesda, Maryland, USA 


\section{EDITORS' FOREWORD}

This book, the first in an annual series, written by academiciansscientists, philosophers and others - is not intended exclusively for animal welfarists and conservationists. Since it is written* by scholars, it will appeal to a wide range of academic and professional readers who are involved with animals for scientific, economic, altruistic, and other reasons. While this first volume cannot cover the entire spectrum of animal welfare science-related topics, it does, in its diversity of contributions, demonstrate the multi-faceted and interdisciplinary nature of the subject of this new series.

Indeed, animals are as much an integral part of society as we are dependent upon them. The many interfaces between us and the billions of animals under our dominion (as well as the environment upon which the welfare of human and non-human animals alike is ultimately dependent) have their separate features: trapping and wildlife management; laboratory animal research; whaling and fishing; veterinary practice; agriculture and farm animal husbandry; horse racing and the ownership of animal companions; the propagation of captive wildlife and their preservation in the wild; the use of animals as companions and for the purposes of vicarious entertainment.

These interfaces are linked by the science of animal welfare which, by virtue of its interdisciplinary nature, includes such disciplines as ethology, veterinary medicine, psychology, physiology, farm animal production technologies; studies of human attitudes towards animals (including cross-cultural anthropology) and the legal protection of animals; humane education, law enforcement, legislation, and ethics of moral philosophy and enlightened self-interest; practical problems such as predator control, euthanasia of unwanted pets and the transportation and slaughter of farm animals; and such issues and questions as animal sentience, sapience, awareness, needs and rights.

Ethics and philosophy have become divorced from science, as values have from facts. Yet ethics and moral philosophy are an integral

\footnotetext{
*All articles submitted and solicited are subject to refereeing by members of the Manu-
} script Review Committee (see Instructions to Authors). 
part of animal welfare science, as are economics, cultural values, perceptions, and social customs. In sum, the scholarly, as distinct from the "objective"*, study of animal welfare embraces all these disciplines and aspects of human-animal relationships. It is a complex and diverse field of inquiry which, through this new annual publication, will gain the international recognition and attention that the subject has long deserved.

"and through the "objectification" of the world, we have achieved considerable power and control over life, yet in the process, have created a multitude of ethical, environmental, social, economic, and other global problems, one major one being the wellbeing of the animal kingdom. 


\section{LIST OF CONTENTS}

Editors' Foreword $\ldots \ldots \ldots \ldots \ldots \ldots \ldots \ldots \ldots \ldots \ldots \ldots \ldots \ldots$

I. ANIMAL AWARENESS

THE QUESTION OF ANIMAL AWARENESS

F. Wemelsfelder

\section{HUMAN/ANIMAL RELATIONSHIPS}

THE ORIGINS OF EMPATHY AND ALTRUISM

C. Zahn-Waxler, B. Hollenbeck, and M. Radke-Yarrow

ATTITUDES TOWARD ANIMALS: AGE-RELATED

DEVELOPMENT AMONG CHILDREN

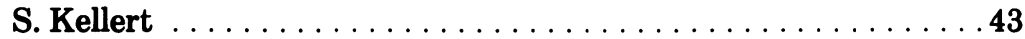

EMPATHY, HUMANENESS AND ANIMAL WELFARE

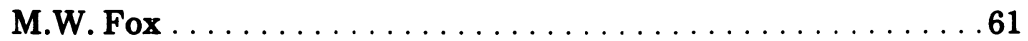

HUMAN/ANIMAL COMMUNICATION: CETACEAN ROLES

IN HUMAN THERAPEUTIC SITUATIONS

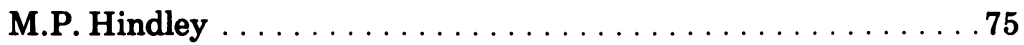

\section{ANIMAL RIGHTS}

LOGIC AND LIMITS OF ANIMAL LIBERATION

E.R. Bennett $\ldots \ldots \ldots \ldots \ldots \ldots \ldots \ldots \ldots \ldots \ldots \ldots$

WHALES ARE NOT CETACEAN RESOURCES

D. Jamieson and T. Regan $\ldots \ldots \ldots \ldots \ldots \ldots \ldots \ldots \ldots$

IV. ANIMAL MANAGEMENT

ANIMAL BOREDOM: IS A SCIENTIFIC STUDY OF THE SUBJECTIVE EXPERIENCES OF ANIMALS POSSIBLE?

F. Wemelsfelder . . . . . . . . . . . . . . . . . . . . . 115

EVILS OF MODERN STABLES

J.I. Lupton .

STEREOTYPE BEHAVIOUR IN SOWS AND GILTS HOUSED IN STALLS, TETHERS, AND GROUPS

J.K. Blackshaw and J.F. McVeigh

\section{APPENDIX}

AMERICAN ATTITUDES TOWARD AND KNOWLEDGE OF ANIMALS: AN UPDATE

S. Kellert . . . . . . . . . . . . . . . . . . . . . . . 177

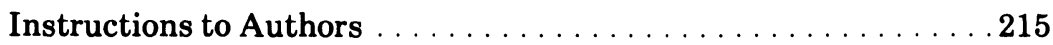

